\title{
Impact of silver nanoparticles as antibacterial agent derived from leaf and callus of Celastrus paniculatus Willd
}

\author{
Anita Solanki ${ }^{1}$, Dipika Rathod ${ }^{2}$, Illa C. Patel ${ }^{1}$ and Jitendriya Panigrahi ${ }^{3^{*}}$ (D)
}

\begin{abstract}
Background: Celastrus paniculatus Willd. is a rich source of numerous active constituents such as celapanigin, celapagin, malkangunin, celapanin, zeylasteral, pristimerin, and zeylasterone which render medicinal properties to its various parts. Therefore, the present work provides a protocol for the synthesis of AgNPs from in vivo leaf and in vitro developed callus extract of C. paniculatus and both the extracts have great antibacterial potential, which may give immense support for the drug preparation using AgNPs prepared from this valuable medicinal plant.

Results: High frequencies of calli induced from leaves and its counterpart, i.e., the natural part leaf were selected as the experimental materials for the green synthesis. The collected data exhibited gradual color variations started with whitish color, creamish, and after 8 weeks it ultimately turns into a solid mass of brownish callus. The silver nanoparticles (AgNPs) were synthesized using in vivo fresh leaves and in vitro developed callus extracts with an indication of brown colored complex. Further confirmation of AgNPs synthesis in both the samples was done using UV-visible spectral analysis followed by X-ray diffraction (XRD) analysis, Fourier transformation infrared spectroscopy (FTIR), and scanning electron microscopic (SEM) analysis.

Conclusion: The antibacterial activity of both extracts reflected the presence of the zone of inhibition in both gram-positive and gram-negative bacteria. AgNPs derived from callus extract showed better results with $24.00 \pm$ $1.00 \mathrm{~mm}$ zones of inhibition. This protocol deserves the recognition of the antibacterial potential of AgNPs synthesized from CP plant extracts.
\end{abstract}

Keywords: Antibacterial activity, Celastrus paniculatus, SEM, Silver nanoparticles, Silver nitrate

\section{Background}

In the current situation, nanotechnology is an advanced field that deals with the green synthesis of nanoparticles at nano levels using smaller scales below $1 \mu \mathrm{m}$ /normally from 1 to $100 \mathrm{~nm}$ [1]. The detailing of nanoparticles is a significant component of nanotechnology since its particular characters are characterized at the degree of nanoparticles, nanocrystals, or nanolayers and are valuable in different fields of science, for example, physical, synthetic, and natural just as drug applications [2].

\footnotetext{
* Correspondence: jitenp2001@gmail.com

${ }^{3}$ Department of Biotechnology, Shri A.N. Patel P.G. Institute of Science and Research, Anand, Gujarat 388001, India

Full list of author information is available at the end of the article
}

These particles are of great scientific interest for research due to their different characteristics and large surface area/volume ratio [3].

Silver nanoparticles are one of the noble metal-based nanoparticles. Besides, silver nanoparticles have attracted particular attention because of their unique properties, including antimicrobial activities, catalytic, chemical stability, and electrical conductivity $[4,5]$. Also, silver ion behaves completely different properties in the nanoscale as compared to bulk particles prepared from similar material [6]. Silver is used in several medical products such as skin ointments, creams used to cure burns and open wounds [7]. But, chemically synthesized AgNPs reported toxic in their chemical form so that

\section{Springer Open}

(อ) The Author(s). 2021 Open Access This article is licensed under a Creative Commons Attribution 4.0 International License, which permits use, sharing, adaptation, distribution and reproduction in any medium or format, as long as you give appropriate credit to the original author(s) and the source, provide a link to the Creative Commons licence, and indicate if changes were made. The images or other third party material in this article are included in the article's Creative Commons licence, unless indicated otherwise in a credit line to the material. If material is not included in the article's Creative Commons licence and your intended use is not permitted by statutory regulation or exceeds the permitted use, you will need to obtain permission directly from the copyright holder. To view a copy of this licence, visit http://creativecommons.org/licenses/by/4.0/. 
plant-based AgNPs have demonstrated vast application as green synthesis as compared to pure individual physical and chemicals methods because it is a low cost, ecofriendly, and simply advanced technology for large-scale synthesis of nanoparticles. Moreover, there is no need for special temperature, high pressure, further use of energy, and hazardous chemicals [8]. The biological synthesis of inorganic nanoparticles makes nanoparticles more biocompatible and less harmful to the environment [9]. Furthermore, dependable attempts have been made for the search of techniques or protocols by employing the plants and microorganisms to synthesize silver and gold nanoparticles [10]. Until now, several medicinal plants were used to synthesize the leaf-based nanoparticles as Medicago sativa L. [11], Acalypha indica L. [12], Garcinia mangostana L. [13], Catharanthus roseus [14], and Ocimum americanum L. [15].

Celastrus paniculatus Willd. popularly known as Malkangani, Jyotishmati, or memory-enhancing plant is used in curing several human ailments like dysentery, diarrhea, fever, and digestive disorders such as loss of appetite, constipation, and abdominal distension [16]. The leaves of this plant are emmenagogue and the fresh leaf juice is a worthy remedy against opium poisoning. The dried powdered form of leaves, flowers, fruits, and seeds is recommended for the regular intake to heal mental disorders and enhance mental power, whereas the swellings and fractures are treated exogenously with boiled leaves pest [17]. CP plant parts specifically leaves are a rich source of several secondary metabolites protein, polyphenol, carbohydrate, flavonoids, and terpenoids [18]. It is a rich source of many Phytochemicals that help as capping and stabilizing agents for the synthesis of AgNPs. Besides this, several reports are also available on tissue-cultured-derived plant or callus extract that was also involved in the green synthesis, as seen in the Carica papaya [18] and Sesuvium portulacastrum [19]. In $\mathrm{CP}$, work on the use of in vivo leaves extract for the synthesis of AgNPs was recorded by Ramana et al. [20]. The in vitro multiplication of tissues/ plants parts/ callus in CP was already evidenced and plants itself area rich source of phytochemicals and various proteins in both in vivo and in vitro parts [1, 21, 22]. But, limited reports are available on the green synthesis of AgNPs by using in vitro tissues/ callus. The present study illustrates the green synthesis of AgNPs both from in vivo leaves and in vitro-derived callus of $\mathrm{CP}$ and followed by its characterization by various techniques and also analyze its antibacterial potential on Pseudomonas aeruginosa, Escherichia coli, Staphylococcus aureus, and Bacillus subtilis.

\section{Methods}

Selection and surface sterilization of explants

All the explants and in vivo leaf samples of Celastrus paniculatus Willd. were collected. It was washed thoroughly with tap water and excised young leaves of CP have further sterilized with $70 \%(\mathrm{v} / \mathrm{v})$ ethyl alcohol for $30 \mathrm{~s}$ followed by $0.1 \%(\mathrm{w} / \mathrm{v}) \mathrm{HgCl}_{2}$ for 10 to $15 \mathrm{~s}$ and finally, 2-3 times rinsed with double distilled water and used for callusing.

\section{Callus formation and in vitro culture condition}

For the induction of callus, the sterilized leaves were inoculated into in vitro Murashige and Skoog medium (MS) [23] supplemented with different concentrations of $\operatorname{BAP}(0.5,1,2 \mathrm{mg} / \mathrm{l}), 2,4-\mathrm{D}(1,2,3 \mathrm{mg} / \mathrm{l}), \mathrm{Kn}(0.5,0.1$ $\mathrm{mg} / \mathrm{l})$ alone and an optimal combination of $\operatorname{BAP}(0.5,1.2$ $\mathrm{mg} / \mathrm{l})$ with varying concentrations of 2.4-D (0.5. $1 \mathrm{mg} / \mathrm{l})$ and $\mathrm{Kn}(1.2 \mathrm{mg} / \mathrm{l})$. All the cultures were maintained at a temperature of $25 \pm 2{ }^{\circ} \mathrm{C}$. The intensity of illumination was 3500 Lux with $16 / 8$ h dark and light regime. Subculturing was done with regular intervals of 15-20 days in the same media for maximum induction and proliferation of callus.

\section{Preparation of aqueous extracts of in vivo leaves and in vitro callus}

The in vitro developed fresh calli and in vivo leaves were dried in an oven at $40{ }^{\circ} \mathrm{C}$ for $24 \mathrm{~h}$. The dried $5 \mathrm{~g}$ of fine powder of both the samples was taken into $250 \mathrm{ml} \mathrm{Er}$ lenmeyer flask separately and then $50 \mathrm{ml}$ of sterile double distilled water was poured into it and boiled for $10 \mathrm{~min}$ at $70{ }^{\circ} \mathrm{C}$. It was cooled and filtered using Whatman No. 1 filter paper. The filtered extract of leaves and calli were used for the biosynthesis of silver nanoparticles. Both extracts were stored at $4{ }^{\circ} \mathrm{C}$ for further study.

\section{Bio-synthesis of AgNPs}

Pure silver nitrate procured from Himedia, Bangalore, India. The solution of $1 \mathrm{mM} \mathrm{AgNO}$ was added dropwise in the reaction mixture of $\mathrm{CP}$ extracts with a ratio of 1:9 ratio-optimized concentrations $(10 \mathrm{ml}$ of extract to $90 \mathrm{ml}$ aqueous solution of $1 \mathrm{mM} \mathrm{AgNO}$ ) in $250 \mathrm{ml}$ Erlenmeyer flask separately and both were dark incubated at $35{ }^{\circ} \mathrm{C}$ for about $48 \mathrm{~h}$. The reduction of silver ions $\left(\mathrm{Ag}^{+}\right)$to $\mathrm{AgNPs}\left(\mathrm{Ag}^{0}\right)$ was achieved by conversion of color from light yellow to dark brown followed by spectrophotometry analysis [24].

\section{Characterization of synthesized silver nanoparticles}

UV-visible spectroscopy was used for the surface plasmon resonance peak (SPR) characteristic of the AgNPs solution of each sample separately. The reduction of pure $\mathrm{Ag}+$ ions was monitored by measuring the UV-vis spectrum of the reaction mixture by diluting a small aliquot of both the samples into double distilled water over a range of 300-600 $\mathrm{nm}$ using Elico-India UV-VIS double beam PC Scanning spectrophotometer [25]. The crystalline features of AgNPs were noticed during the 
$\mathrm{Cu} \mathrm{K} \alpha$ radiation source on an Ultima IV X-ray powder diffractometer (Rigaku, Tokyo, Japan) [24]. X-ray diffraction analysis was operated by following the method of Kumari and Singh [26]. The important functional groups were determined on a Jasco FTIR-16100 instrument in the range $4000-500 \mathrm{~cm}^{-1}$ at a resolution of $2 \mathrm{~cm}^{-1}$ [25]. The size details and morphology of AgNPs understand by the scanning electron microscopy operating at 200 Kv [27].

\section{Antibacterial activity by agar well diffusion method}

The silver nanoparticles synthesized using leaves and callus extracts were used to study antibacterial activity by the agar well diffusion method. The cultures used for antibacterial activity with pathogenic isolates were Escherichia coli, Pseudomonas aeruginosa, as gramnegative and Bacillus subtilis, Staphylococcus aureus as gram-positive bacteria. The three different concentrations of silver Nanoparticles samples $(40 \mu \mathrm{l}, 50 \mu \mathrm{l}$, and $60 \mu \mathrm{l})$ were poured into each well on all plates using a sterile micropipette along with streptomycin as positive control and stored in the incubator for $24 \mathrm{~h}$ at $37^{\circ} \mathrm{C}$. The zone of bacterial inhibition was observed and measured [28].

\section{Results}

\section{Callus formation}

The callus induction was significant, i.e., $100 \%$ growth response when inoculating the leaves of $\mathrm{CP}$ in $1.0 \mathrm{mg} / \mathrm{l}$ of BAP. Although, less than this concentration of BAP, $0.5 \mathrm{mg} / \mathrm{l}$ and $2.0 \mathrm{mg} / \mathrm{l} \mathrm{BAP}$ did not provide for suitable calli induction (Table 1). It was followed by $2,4 \mathrm{D}(1 \mathrm{mg} /$ l) alone and a combination of BAP $+\mathrm{Kn}((2+2 \mathrm{mg} / \mathrm{l})$ that responded similarly and shows $86 \%$ growth (Table
1). The initially growing callus was whitish in color and slow-growing, but after 2 weeks it became slightly greenish with a friable texture. After 4 weeks, it turned from light green to dark green and then to become a compact brownish solid callus at the end of 8 weeks (Fig. 1e). After 8 weeks, the calli were collected and used for the synthesis of AgNPs, considering their maturity and brownish color.

\section{UV-visible spectroscopy}

With the addition of callus and leaf extracts with $1 \mathrm{mM}$ $\mathrm{AgNO}_{3}$ solution, color change initially appeared from yellow to brown. It was due to the reduction of $\mathrm{Ag}^{+}$to $\mathrm{Ag}^{0}$ (Fig. 2a, c). The spectra of AgNPs synthesized from $\mathrm{CP}$ in vivo leaves and in vitro-derived callus were recorded after time intervals of $2 \mathrm{~min}, 30 \mathrm{~min}, 1 \mathrm{~h}, 2 \mathrm{~h}$, and $24 \mathrm{~h}$ from the beginning of the reaction (Fig. 3a, b). The color intensity was noted to increase with an increase in the reaction time (Fig. $2 b, d$ ). The absorption spectrum of callus and leaves extracts revealed a peak at $441 \mathrm{~nm}$ and 436 in callus and leaves respectively. It indicated that there was no characteristic SPR peak observed at the initial stage $(2 \mathrm{~min})$. After $1 \mathrm{~h}$, the SPR peak started to appear in the visible range at $435 \mathrm{~nm}$ and became more prominent after some time. With increasing reaction time, the SPR peak became more intense and indicated the biogenic synthesis of silver nanoparticles.

\section{X-ray diffraction analysis (XRD)}

The X-ray diffraction pattern of silver nanoparticles clearly showed, under the 2 theta angle, the main peaks at $32.025,46.081,64.30$, and 76.638 corresponding to the planes (289), (154), (220), and (76), synthesized from the in vivo leaves extracts of CP (Fig. 4a). A face-centric

Table 1 Effect of different hormones on callus formation from leaf explants of CP Willd.

\begin{tabular}{|c|c|c|c|c|c|c|}
\hline \multirow{2}{*}{$\begin{array}{l}\text { Name of } \\
\text { hormones }\end{array}$} & \multirow{2}{*}{$\begin{array}{l}\text { Hormonal } \\
\text { concentration } \\
\text { (mg/l) }\end{array}$} & \multicolumn{4}{|c|}{ Callus induction (in weeks) } & \multirow{2}{*}{$\begin{array}{l}\% \text { growth } \\
\text { frequency }\end{array}$} \\
\hline & & 2 Weeks & 4 Weeks & 6 Weeks & 8 Weeks & \\
\hline \multirow[t]{3}{*}{$2,4 \mathrm{D}$} & 1.0 & + & + & ++ & +++ & 86 \\
\hline & 2.0 & - & + & ++ & +++ & 75 \\
\hline & 3.0 & - & + & + & + & 20 \\
\hline \multirow[t]{3}{*}{ BAP } & 0.5 & - & + & + & + & 20 \\
\hline & 1.0 & + & + & ++ & ++ & 100 \\
\hline & 2.0 & - & + & + & ++ & 60 \\
\hline \multirow[t]{2}{*}{ Kin. } & 0.5 & - & + & + & ++ & 55 \\
\hline & 1.0 & - & + & ++ & +++ & 80 \\
\hline \multirow[t]{2}{*}{$\mathrm{BAP}+2,4 \mathrm{D}$} & $0.5+0.5$ & - & + & ++ & +++ & 50 \\
\hline & $1+1$ & - & + & ++ & ++ & 60 \\
\hline \multirow[t]{2}{*}{ BAP +Kin } & $1+1$ & - & + & ++ & ++ & 50 \\
\hline & $2+2$ & + & ++ & ++ & +++ & 86 \\
\hline
\end{tabular}

Note: ' $+{ }^{\prime}=$ slow growth, ' $++{ }^{\prime}=$ moderate growth, ' $+++{ }^{\prime}=$ rapid growth (placed after callus description in the "Results" section) 

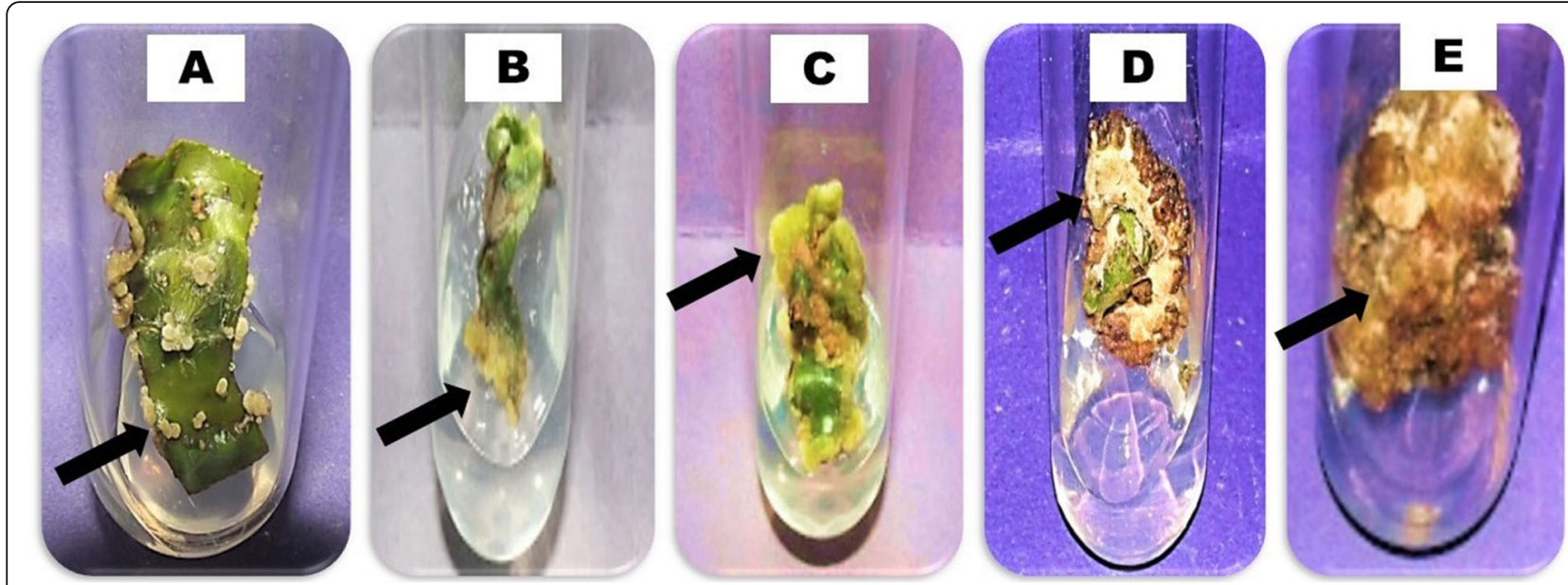

Fig. 1 In vitro callus induction at different time intervals in CP from leaves explant. a Initiation of callus. b After 2 weeks. c After 4 weeks. d After 6 weeks. e After 8 weeks

cubic structure was displayed in AgNPs. Besides, two unassigned peaks appeared at 56.29 and 74.25 . These two peaks were lower than those of silver. In the callusderived AgNPs, the prominent peaks observed at 32.50, 46.11, 64.37, and 77.30 corresponding to the (188.6), (216), (106.1), and (90) planes, respectively (Fig. 4b). Similar to leaf extract, two unassigned peaks were observed at 59.79 and 85.61 .

\section{Fourier transform infrared spectroscopy (FTIR)}

FTIR spectra of leaf extract-AgNPs showed main peaks at $4000 \mathrm{~cm}^{-1}$ to $600 \mathrm{~cm}^{-1}$ (Fig. 5a). It shows specific peaks at $3351 \mathrm{~cm}^{-1}$ (meant for $\mathrm{O}-\mathrm{H}$ stretching for alcohols), 2929 and $2427 \mathrm{~cm}^{-1}$ for $\mathrm{O}-\mathrm{H}$ stretching of carboxylic group, $1580 \mathrm{~cm}^{-1}$ meant for $-\mathrm{C}=\mathrm{C}$ aromatic ring, $1384 \mathrm{~cm}^{-1}$ for $-\mathrm{C}-\mathrm{N}$ stretching of an aromatic amine group, $1092 \mathrm{~cm}^{-1}$ for aliphatic amine phenol/
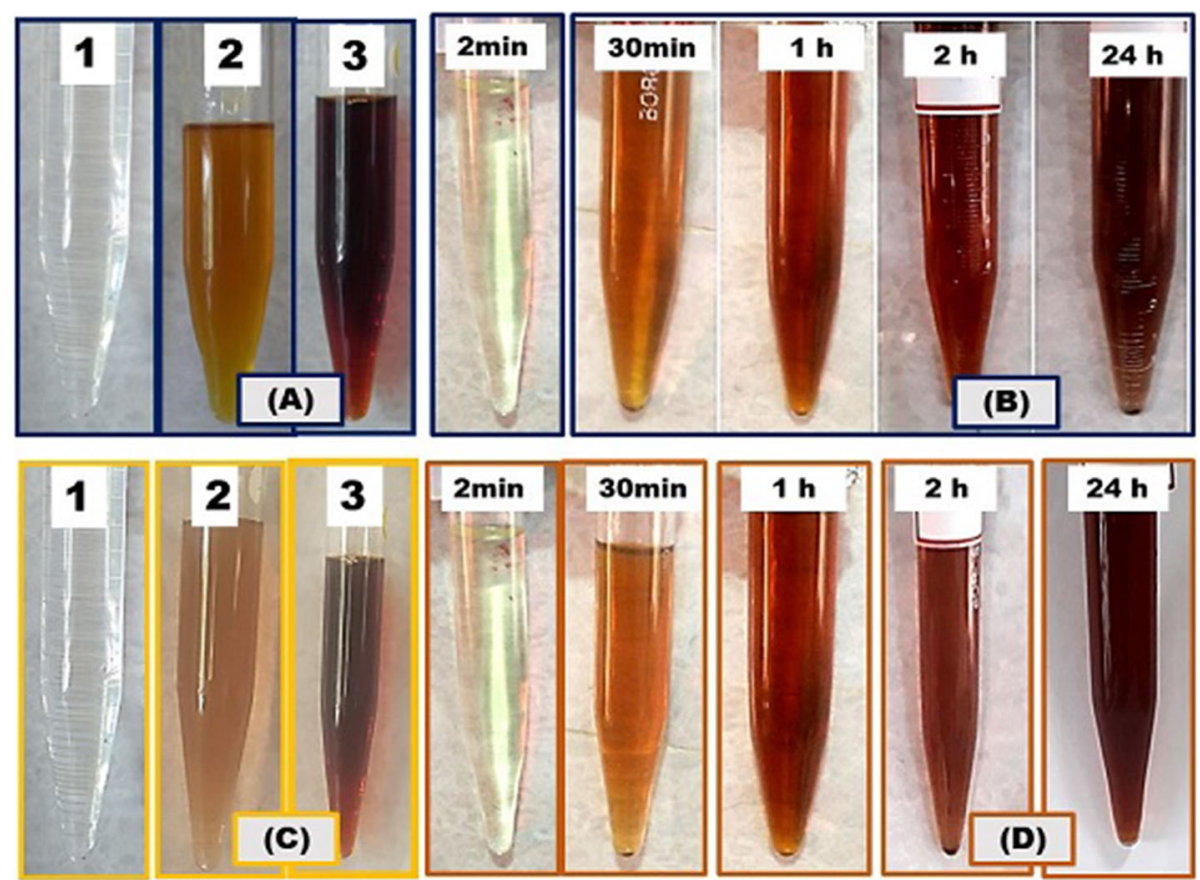

Fig. 2 a (1) $\mathrm{AgNO}_{3}$ solution (2) CP leaf extract (3) Synthesized AgNPs. b Showing color intensity of CP leaf extract after time intervals of 2 min, 30 min, 1 h, 2 h, and 24 h. c (1) $\mathrm{AgNO}_{3}$ solution (2) CP callus extract (3) synthesized AgNPs. d Showing color intensity of CP callus extract after time intervals of $2 \mathrm{~min}, 30 \mathrm{~min}, 1 \mathrm{~h}, 2 \mathrm{~h}$, and $24 \mathrm{~h}$ 

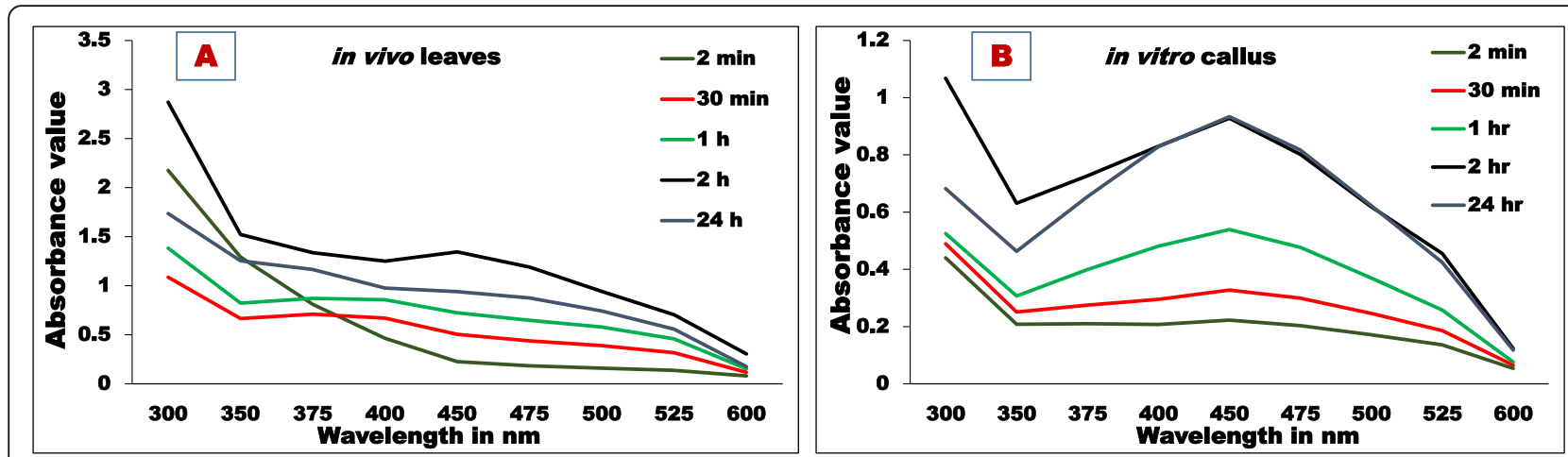

Fig. 3 The UV-visible spectra of AgNPs synthesized from CP in vivo leaves and in vitro-derived callus were recorded after time intervals of 2 min, $30 \mathrm{~min}, 1 \mathrm{~h}, 2 \mathrm{~h}$, and $24 \mathrm{~h}$ from the beginning of the reaction in a leaf extract, $\mathbf{b}$ callus extract

alcohol and lastly $1048 \mathrm{~cm}^{-1}$ for secondary alcohols/carboxylic/ester group. There were 5 FTIR peaks obtained from callus extract-AgNPs, i.e., at 2925, 2854, 1746, 1384, and $1150 \mathrm{~cm}^{-1}$ (Fig. 5b). The observed peaks denote carboxylic group, $-\mathrm{CH}$ alkaline bonds, $-\mathrm{C}=\mathrm{O}$ ester, $-\mathrm{C}-\mathrm{N}$, and $-\mathrm{C}-\mathrm{C}$ stretch, respectively.

\section{Scanning electron microscopy (SEM)}

SEM analysis was performed to determine the morphology and size of the silver nanoparticles synthesized from CP leaves and callus extracts. The SEM micrograph (Fig. 6a, b) indicates that the AgNPs synthesized in the sample were cubic nanoparticles that were distributed randomly over the residues. The average diameter of the nanospheres was between 32 and $57 \mathrm{~nm}$. All particles were uniform and well dispersed without larger aggregations. The shape of the AgNPs may be due to the availability of different quantities and the nature of the capping agents present in the leaf and callus extracts. This is also supported by the shifts and differences in areas of the peaks obtained in the FTIR analysis in the present study. The obtained results from FE-SEM strongly confirmed that Celastrus paniculatus leaf and callus extracts might act as a reducing and capping agent in the production of silver nanoparticles.

\section{Antibacterial activity}

The effective inhibition of bacterial growth was observed by the silver nanoparticles and positive control (streptomycin) after $24 \mathrm{~h}$ of incubation in contrast to the negative control discs without any ZOI (Table 2). AgNPs exhibited significant bacterial activity against grampositive as compared to gram-negative bacteria E. coli, $P$. aeruginosa. According to Table 2, it was evident that the maximum ZOI of $22.16 \pm 1.52 \mathrm{~mm}$ shown by AgNPs prepared from $C P$ leaf extracts towards $S$. aureus, while a lesser degree of ZOI was observed serially in B. subtilis $(21.33 \pm 1.25 \mathrm{~mm})$ as gram-positive and $P$. aeruginosa $(21.67 \pm 0.25 \mathrm{~mm})$ and $E$. coli $(21.66 \pm 0.76 \mathrm{~mm})$ as gram-negative bacteria.

Whereas in the case of the callus synthesized AgNPs, the maximum ZOI was observed in B. subtilis (24.00 \pm $1.00 \mathrm{~mm})$. It was higher than the other bacteria like $E$. coli $(23.00 \pm 0.50 \mathrm{~mm})$, P. aeruginosa $(22.33 \pm 0.57 \mathrm{~mm})$, and $S$. aureus $(21.50 \pm 0.50 \mathrm{~mm})$. These data were statistically significant when calculated by Duncan's multiple tests [29] as post hoc and one-way analysis of variance

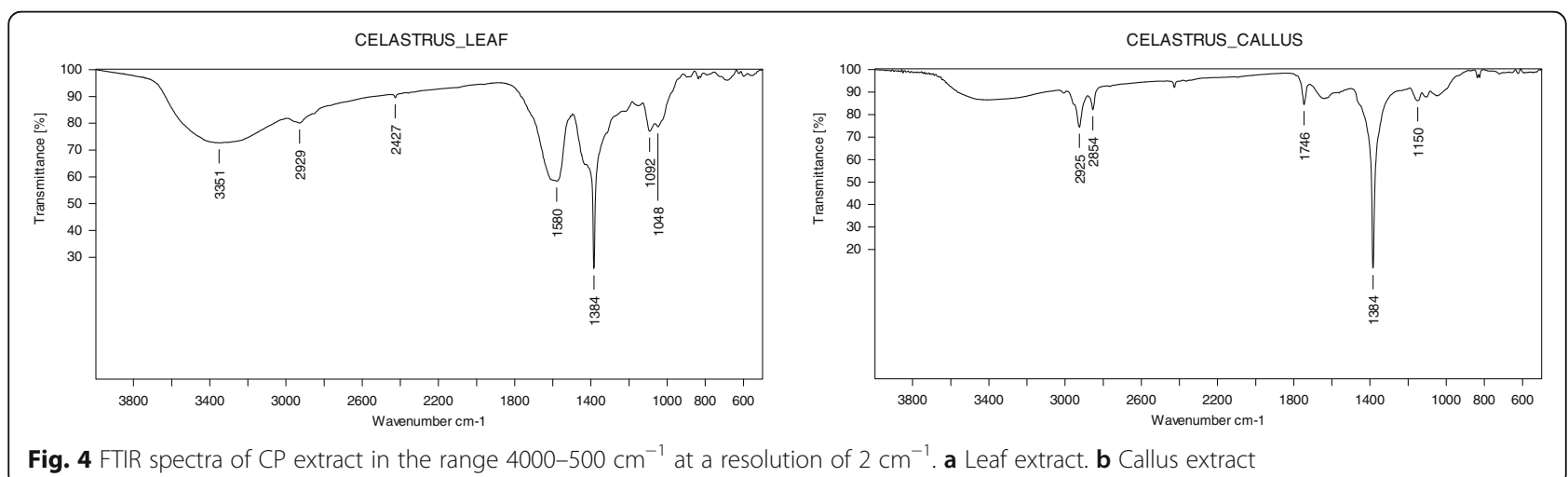



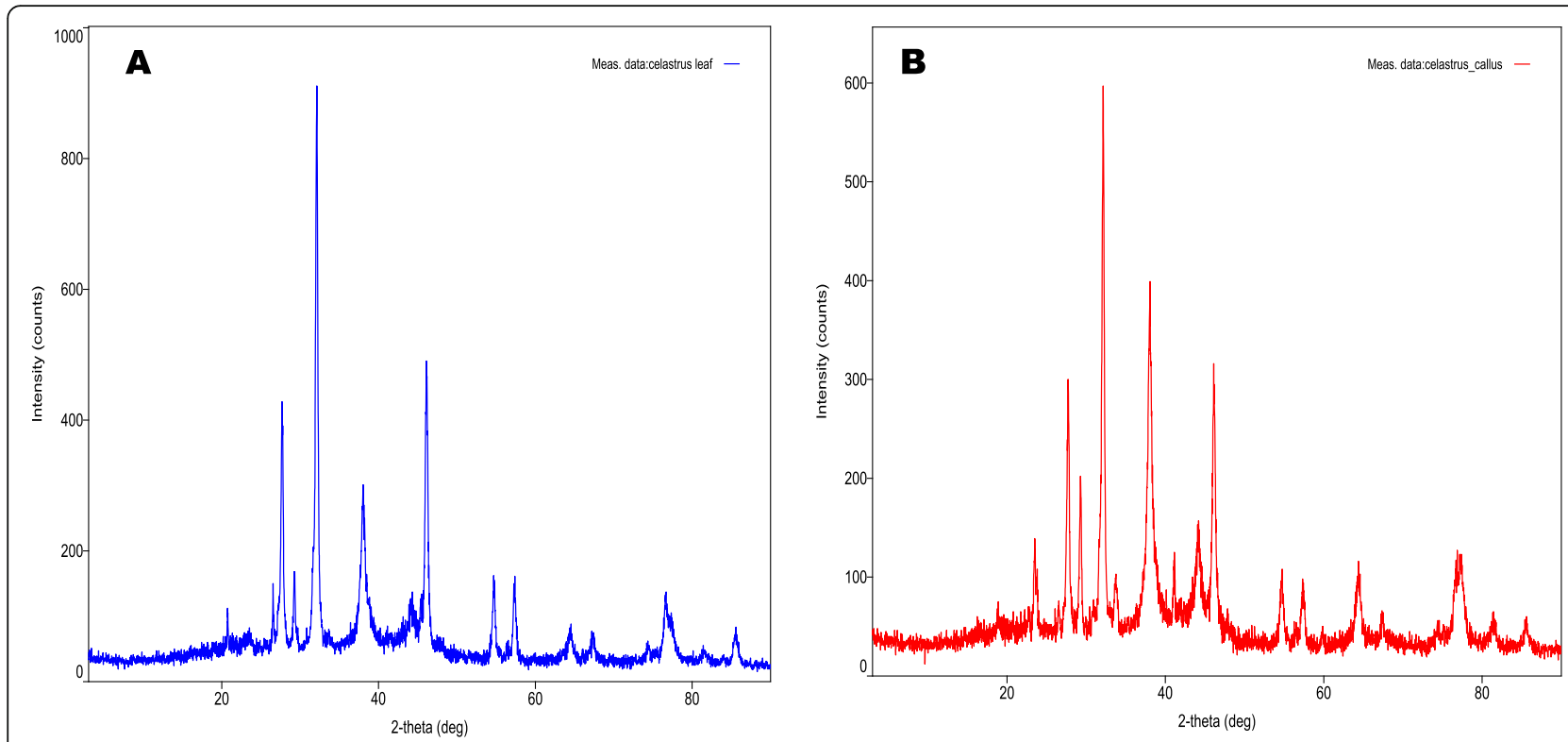

Fig. 5 XRD analysis of a leaf extract and $\mathbf{b}$ Callus extract plotted by theta (degree) versus intensity (counts)

by using SPSS (Ver. 11, SPSS Inc. Chicago, USA) software.

\section{Discussion}

Green nanoparticle synthesis is an environmentally friendly process for the synthesis of silver nanoparticles [30]. However, the use of plants for the production of nanoparticles has attracted the attention of researchers as a fast, inexpensive, and single step for the biosynthesis process. The development of a simple, safe, and green synthetic path would provide further charm in the synthesis and application of silver nanoparticles [31]. The synthesis of silver nanoparticles using in vivo leaf and in vitro-derived callus was an important innovative green technology for modern material science. The nanoparticles are meant to trap the desired molecules and released them in their proper form to the targeted sites $[32,33]$. Here, the main aim was to make the silver nanoparticles both from leaf and callus and try to observe the impact of its antibacterial activities. By various parameters, the nanoparticles were characterized followed by their implications over the different bacteria by measuring the zone of inhibitions.

Callus formation occurred from the leaf explants after 8 weeks of inoculation on MS medium. After 8 weeks, callus becomes matured and brownish which helps in the synthesis of silver nanoparticles may be due to the presence of secondary metabolites. These phytochemicals act
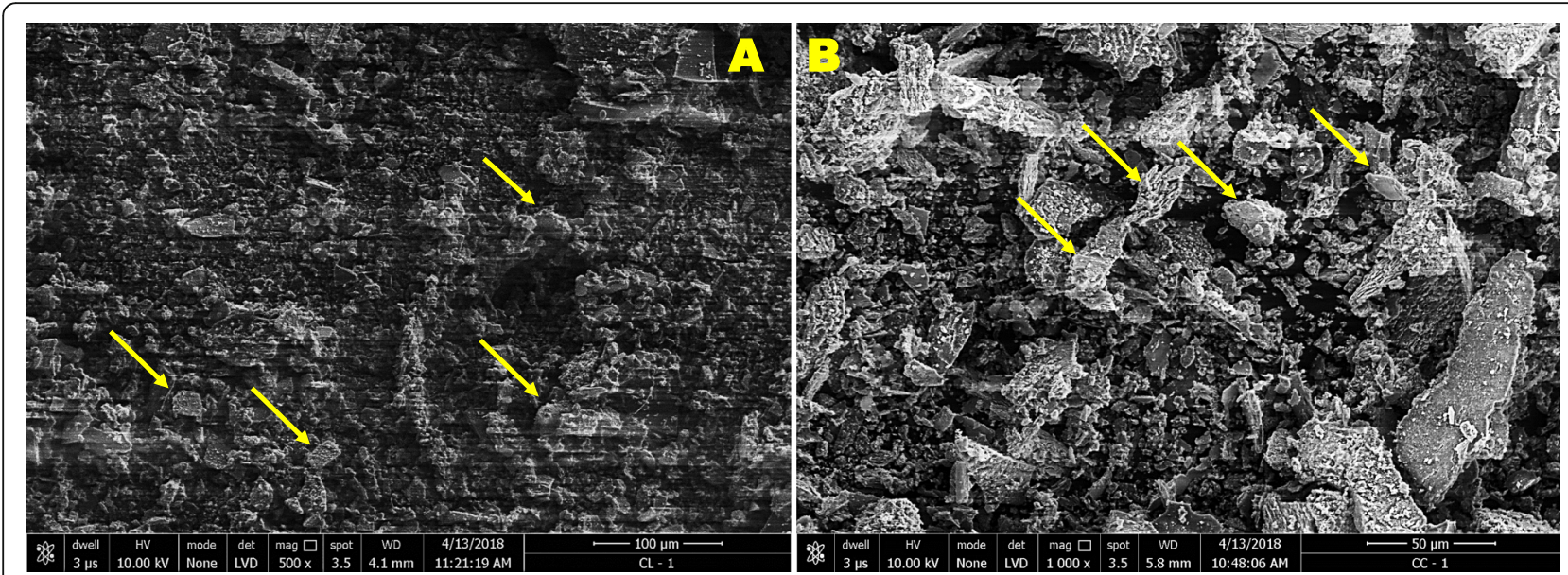

Fig. 6 Scanning electron micrograph of a leaf extract and $\mathbf{b}$ callus extract shows the characteristic depth at $100 \mu \mathrm{m}$ scale and $50 \mu \mathrm{m}$ scale, respectively. The arrow marks indicate the cubic nanoparticles in both leaf and callus extract 
Table 2 Antibacterial activity of silver nanoparticles synthesized by using CP leaf and callus extract against various microorganisms. The data were statistically evaluated through one-way analysis of variance. The data represents mean \pm standard deviation. Data for each column in the respective bacteria followed by the different letters (a to h) are significantly different according to Duncan's multiple range test [29] at $P<0.05$. These letters ( $\mathrm{a}$ to $\mathrm{h}$ ) usually compare the means of different concentrations and the treatments

\begin{tabular}{|c|c|c|c|c|c|}
\hline \multirow{3}{*}{$\begin{array}{l}\text { Name of the } \\
\text { organisms }\end{array}$} & \multirow[t]{3}{*}{ Concentrations } & \multicolumn{4}{|c|}{ Zone of inhibition $(\mathrm{mm})$} \\
\hline & & \multicolumn{2}{|c|}{ Celastrus leaf sample } & \multicolumn{2}{|c|}{ Celastrus callus sample } \\
\hline & & Plant extract & AgNPs & Callus extract & AgNPs \\
\hline \multirow[t]{5}{*}{ Escherichia coli } & $40 \mu \mathrm{l}$ & $13.06 \pm 0.40^{\mathrm{a}}$ & $19.50 \pm 0.5^{d}$ & $15.83 \pm 0.76^{\mathrm{b}, \mathrm{c}}$ & $20.16 \pm 0.76^{\mathrm{d}, \mathrm{e}}$ \\
\hline & $50 \mu l$ & $13.83 \pm 0.76^{\mathrm{a}}$ & $20.73 \pm 0.87^{d, e, f}$ & $15.90 \pm 0.49^{\mathrm{b}, \mathrm{c}}$ & $20.83 \pm 0.85^{e, f}$ \\
\hline & $60 \mu \mathrm{l}$ & $15.23 \pm 0.68^{b}$ & $21.66 \pm 0.76^{f}$ & $16.66 \pm 0.57^{c}$ & $23.00 \pm 0.50^{9}$ \\
\hline & Positive control & $33.00 \pm 1.00^{h}$ & & & \\
\hline & Negative control & 0 & & & \\
\hline \multirow[t]{5}{*}{ Pseudomonas sp. } & $40 \mu \mathrm{l}$ & $14.50 \pm 0.50^{\mathrm{a}}$ & $19.16 \pm 1.25^{d}$ & $15.83 \pm 0.76^{\mathrm{b}, \mathrm{c}}$ & $20.50 \pm 0.50^{e}$ \\
\hline & $50 \mu \mathrm{l}$ & $15.66 \pm 0.76^{a, b, c}$ & $21.00 \pm 1.00^{\mathrm{e}}$ & $15.06 \pm 0.60^{a, b}$ & $21.52 \pm 0.50^{e, f}$ \\
\hline & $60 \mu \mathrm{l}$ & $15.73 \pm 0.25^{a, b, c}$ & $21.67 \pm 0.25^{e, f}$ & $16.83 \pm 0.76^{c}$ & $22.33 \pm 0.57^{9}$ \\
\hline & Positive control & $30.00 \pm 0.50^{h}$ & & & \\
\hline & Negative control & 0 & & & \\
\hline \multirow[t]{5}{*}{ Staphylococcus aureus } & $40 \mu \mathrm{l}$ & $14.66 \pm 0.57^{b, c}$ & $19.00 \pm 0.50^{d}$ & $14.00 \pm 1.00^{b}$ & $20.50 \pm 0.50^{e}$ \\
\hline & $50 \mu \mathrm{l}$ & $15.83 \pm 0.76^{c}$ & $21.16 \pm 1.04^{\mathrm{e}, \mathrm{f}}$ & $16.00 \pm 1.00^{c}$ & $21.66 \pm 1.52^{\mathrm{e}, f}$ \\
\hline & $60 \mu \mathrm{l}$ & $0.00 \pm 0.00^{\mathrm{a}}$ & $22.16 \pm 1.52^{f}$ & $0.00 \pm 0.00^{\mathrm{a}}$ & $21.50 \pm 0.50^{e, f}$ \\
\hline & Positive control & $31.23 \pm 1.07^{\mathrm{g}}$ & & & \\
\hline & Negative control & 0 & & & \\
\hline \multirow[t]{5}{*}{ Bacillus subtilis } & $40 \mu \mathrm{l}$ & $13.00 \pm 1.00^{\mathrm{a}}$ & $18.33 \pm 0.57^{c, d}$ & $13.00 \pm 1.00^{a}$ & $20.73 \pm 0.75^{e}$ \\
\hline & $50 \mu \mathrm{l}$ & $14.16 \pm 0.76^{\mathrm{ab}}$ & $19.16 \pm 0.57^{d}$ & $14.33 \pm 0.76^{a, b}$ & $21.33 \pm 1.25^{\mathrm{e}}$ \\
\hline & $60 \mu \mathrm{l}$ & $15.56 \pm 1.10^{b}$ & $21.33 \pm 1.25^{\mathrm{e}}$ & $17.16 \pm 0.76^{c}$ & $24.00 \pm 1.00^{f}$ \\
\hline & Positive control & $26.33 \pm 0.57^{9}$ & & & \\
\hline & Negative control & 0 & & & \\
\hline
\end{tabular}

as capping and stabilizing agents for silver nanoparticle synthesis. The calli obtained from CP during this study are close to the previous report of Thomas and Philip [34]. Several reports evidenced the use of other hormones like NAA and kinetin [16], IAA and NAA [35], kinetin and IBA [36] promotes the callusing in the leaves of CP. However, the other report [24] suggests that the similarity in calli-derived from leaves of Centella asiatica. It is noteworthy to mention that it is rich in phytochemicals and therefore used for AgNPs synthesis. The above findings confirm with the earlier reports in the leaves of $\mathrm{CP}$ as well [20] and in the leaf of Leptadenia reticulate Retz [37].

The peak of SPR and different molecules of callus extracts could be responsible for the recovery and stabilization of silver nanoparticles [38]. The reduction in the stabilization of silver ions in AgNPs is thought to be due to the involvement of callus proteins and secondary metabolites. This can be approved due to its proteins via its free amino groups or cysteine residues that bind to AgNPs and stabilize AgNPs during biogenesis [19]. This may be due to the bioorganic compounds present on the surface of AgNPs. Unplanned crystalline structures $(56,29$, and 74,25$)$ are appeared to confirm the presence of organic compounds present in leaf extract $[38,39]$.

The visual color change was initially characterized in a visible UV-spectrophotometer. It was examined due to the reduction of $\mathrm{Ag}^{+}$to $\mathrm{Ag}^{0}$. The appearances of dark yellow, dark brown, reddish-brown color solution were consistent with AgNPs synthesis in both the samples through UV-visible spectroscopy. The increased color intensity represents a rapid reduction process to understand the mechanism of increased AgNPs synthesis. Such color change signaled the presence of certain active biomolecules in the two extracts of CP. In both samples, periodic changes in UV-visible absorption peaks were recorded between the range of $420-450 \mathrm{~nm}$, which represents surface plasmon resonance (SPR). The SEM analysis of leaf and callus synthesized AgNPs represented the presence of cubical shaped uniform silver nanoparticles in both samples. Moreover, the average diameter of the nanospheres was ranging between 32 and $57 \mathrm{~nm}$. These peaks were lesser than those of silver and it could be the presence of bioorganic compounds 
on the surface of AgNPs. As in the case of the XRD analysis of the leaves, unplanned crystalline structures (59, 79 and 85,61 ) displayed that indicates the existence of organic compounds of the callus extract [40-42].

The shape of AgNPs may be due to the availability of different amounts and the nature of the styling agents present in the leaf and callus extracts. The study related to FTIR represented the presence of numbers of various functional groups like carbohydrates, flavonoids, polyphenols, proteins, and terpenoids in extracts of leaf and callus. This may be considered to be a reducing, capping, and stabilizing agent that promotes the rapid synthesis of silver nanoparticles. Silver nanoparticles have been reported to be the memorable antibacterial activity against the bacteria. AgNPs may preferentially bind to the cell membrane and cause dissipation of proton motive force (PMF) and thereby causing destruction of the membrane. The action of silver nanoparticles takes place on the surface of the bacterial cell membrane, which disrupts their permeability and their respiratory functions [2]. The use of 8-week calli-derived AgNPs is considered to have a higher potential for the synthesis of silver nanoparticles compared to in vivo leaf. It may be due to interfering with other complex/metabolites in binding with $\mathrm{AgNO}_{3}$ to form nanoparticles. This study will lead to the development of a simple bioprocess for the synthesis of silver nanoparticles and will open a new possibility of very conveniently synthesizing silver nanoparticles using plant parts that will be useful in biomedical applications.

\section{Conclusion}

Plant-based nanoparticles are a significant alternative way of idiomatic expression against chemical and physical methods. AgNPs were effectively synthesized from both in vivo leaves and in vitro developed callus of $C$. paniculatus. In this study, different characterization techniques were used viz. UV-spectra analysis, XRD method, FTIR analysis, and SEM analysis for the confirmation of AgNPs. The antibacterial activity as shown by the use of synthesized AgNPs from plant extract can be recommended in the field of nanomedicine. The synthesis of silver nanoparticles using in vivo fresh leaves and in vitro developed callus in C. paniculatus was found to establish an energetically and economically feasible rapid method using silver nitrate. Besides, this method is very simple and user friendly which do not require any special tools and technique for synthesis. Thus, it can be explored in the field of medicine.

\section{Abbreviations}

CP: Celastrus paniculatus; MS: Murashige and Skoog; BAP-

: ${ }^{6}$ Nbenzylaminopurine; 2,4-D: 2,4-dichlorophenoxyacetic acid; Kn: Kinetin or 6-furfurylaminopurine; UV-Vis: Ultra-violet visible spectroscopy; XRD: X-ray diffraction; FTIR: Fourier transform infrared spectroscopy; SEM: Scanning Electron Microscopy; ZOI: Zone of inhibition

\section{Acknowledgements}

Authors are highly acknowledged to the Head of the Central laboratory and Department of Life Sciences, Hemchandracharya North Gujarat University, Patan, for granting permission to conduct the research analysis. It is to acknowledge the Sicart Institute, Vidyanagar, Gujarat for SEM analysis.

\section{Plant authentication}

All the explants and in vivo leaf samples of Celastrus paniculatus Willd. were collected from the Botanical garden of Life Sciences Department,

Hemchandracharya North Gujarat University, Patan (2351'50" N 72 $8^{\prime} 12^{\prime \prime}$ E) Gujarat, India. The plant was authenticated by Dr. Illa C Patel, Associate Prof in Life Sciences of the same department.

\section{Authors' contributions}

JP and ICP designed and conceptualized the idea; AS and DR carried out the experiments; DR and AS prepared the initial draft. JP and ICP revised and prepared the final draft; All authors approved the final version of manuscript.

\section{Funding}

No funding was obtained for this study.

Availability of data and materials

All data analyzed during this study are included in this manuscript and data and material are available upon request.

\section{Declarations}

Ethics approval and consent to participate

Not applicable

Consent for publication

Not applicable

\section{Competing interests}

The authors declare that they have no competing interests.

\section{Author details}

1 Department of Life Sciences, Hemchandracharya North Gujarat University, Patan, Gujarat 384265, India. ${ }^{2}$ Department of Botany, H.V.H.P. Institute of Post Graduate Studies and Research, Kadi, Gujarat 382715, India. ${ }^{3}$ Department of Biotechnology, Shri A.N. Patel P.G. Institute of Science and Research, Anand, Gujarat 388001, India.

Received: 30 October 2020 Accepted: 21 February 2021

Published online: 04 March 2021

\section{References}

1. Albrecht MA, Evans CW, Raston CL (2006) Green chemistry and the health implications of nanoparticles. G Chem 8(5):17-432. https://doi.org/10.1039/ B517131H

2. Rai M, Yadav A, Gade A (2009) Silver nanoparticles as a new generation of antimicrobials. Bio Adv 27(1):76-83. https://doi.org/10.1016/j.biotechadv.2 008.09.002

3. Wang $Y$, Herron N (1991) Nanometer-sized semiconductor clusters: materials synthesis, quantum size effects, and photophysical properties. J Phy Chem 95(2):525-532. https://doi.org/10.1021/j100155a009

4. Yokoyama K, Welchons DR (2007) The conjugation of amyloid beta protein on the gold colloidal nanoparticles' surfaces. Nano 18(10):105101. https:// doi.org/10.1088/0957-4484/18/10/105101

5. Kumar V, Guleria P, Kumar V, Yadav SK (2013) Gold nanoparticles exposure induces growth and yield enhancement in Arabidopsis thaliana. Sci Total Environ 461:462-468. https://doi.org/10.1016/j.scitotenv.2013.05.018

6. Song JY, Kim BS (2009) Rapid biological synthesis of silver nanoparticles using plant leaf extracts. BioPro Bio Sym Eng 32(1):79. https://doi.org/10.1 007/s00449-008-0224-6

7. Ontong JC, Singh S, Nwabor OF, Chusri S, Voravuthikunchai SP (2020) Potential of antimicrobial topical gel with synthesized biogenic silver 
nanoparticle using Rhodomyrtusto mentosa leaf extract and silk sericin. Bio Lett 18:1-12. https://doi.org/10.1007/s10529-020-02971-5

8. Gardea-Torresdey JL, Gomez E, Peralta-Videa JR, Parsons JG, Troiani H, JoseYacaman M (2003) Alfalfa sprouts: a natural source for the synthesis of silver nanoparticles. Langmuir 19(4):1357-1361. https://doi.org/10.1021/la020835i

9. Govindaraju K, Tamilselvan S, Kiruthiga V, Singaravelu G (2010) Biogenic silver nanoparticles by Solanum torvum and their promising antimicrobial activity. J Bio Pest 3(1):394

10. Huang J, Li Q, Sun D, Lu Y, Su Y, Yang X, Hong J (2007) Biosynthesis of silver and gold nanoparticles by novel sundried Cinnamomum camphora leaf. Nano 18(10):105104. https://doi.org/10.1088/0957-4484/18/10/105104

11. Harris AT, Bali R (2008) On the formation and extent of uptake of silver nanoparticles by live plants. J Nano Res 10(4):691-695. https://doi.org/10.1 007/s11051-007-9288-5

12. Krishnaraj C, Jagan EG, Rajasekar S, Selvakumar P, Kalaichelvan PT, Mohan NJCSBB (2010) Synthesis of silver nanoparticles using Acalypha indica leaf extracts and its antibacterial activity against water borne pathogens. Coll Surf B76(1):50-56. https://doi.org/10.1016/j.colsurfb.2009.10.008

13. Veerasamy R, Xin TZ, Gunasagaran S, Xiang TFW, Yang EFC, Jeyakumar N, Dhanaraj SA (2011) Biosynthesis of silver nanoparticles using mangosteeen leaf extract and evaluation of their antimicrobial activities. J Saudi Chem Soc 15(2):113-120. https://doi.org/10.1016/j.jscs.2010.06.004

14. Kotakadi VS, Rao YS, Gaddam SA, Prasad TNVKV, Reddy AV, Gopal DS (2013) Simple and rapid biosynthesis of stable silver nanoparticles using dried leaves of Catharanthus roseus Linn. G. Donn and its antimicrobial activity. Coll Surf B105:194-198. https://doi.org/10.1016/j.colsurfb.2013.01.003

15. Anuradha G, SyamaSundar B, Ramana MV (2014) Ocimum americanum L. leaf extract mediated synthesis of silver nanoparticles: A novel approach towards weed utilization. Scholars Res Library Arch Appl Sci Res 6(3):59

16. Sharada M, Ahuja A, Kaul MK (2003) Regeneration of plantlets via callus cultures in Celastrus paniculatus Willd-A rare endangered medicinal plant. J Plant Bio Chem Biotech 12(1):65-69. https://doi.org/10.1007/BF03233163

17. Khanna C (2007) Conservation of some useful medicinal plants of Haridwar district in Uttaranchal state. Medicinal Plants: Conservation and Cultivation, Uttaranchal, pp 147-166

18. Mude N, Ingle A, Gade A, Rai M (2009) Synthesis of silver nanoparticles using callus extract of Carica papaya - a first report. J Plant Biochem Bio Tech 18(1):83-86. https://doi.org/10.1007/BF03263300

19. Nabikhan A, Kandasamy K, Raj A, Alikunhi NM (2010) Synthesis of antimicrobial silver nanoparticles by callus and leaf extracts from saltmarsh plant, Sesuvium portulacastrum L. Coll Surf B 79(2):488-493. https://doi.org/1 0.1016/j.colsurfb.2010.05.018

20. Ramana MV, Rao VJR, Anitha P, Sujatha T, Shantkriti S, Rao MC (2015) Synthesis and characterization of silver nanoparticles using Celastrus paniculatus leaf extract. Int J Res Appl Sci Eng Technol 3:958-961

21. AnushaTS JMV, Elyas KK (2016) Callus induction and elicitation of total phenolics in callus cell suspension culture of Celastrus paniculatus-Willd, an endangered medicinal plant in India. Phar J 8(5). https://doi.org/10.5530/pj.2016.5.10

22. Raju NL, Prasad MNV (2007) Cytokinin-induced high frequency shoot multiplication in Celastrus paniculatus Willd., a red listed medicinal plant. Med Aro Plant Sci Biol 1:133-137

23. Murashige T, Skoog F (1962) A revised medium for rapid growth and bio assays with tobacco tissue cultures. Phys Plan 15(3):473-497. https://doi. org/10.1111/j.1399-3054.1962.tb08052.x

24. Netala VR, Kotakadi VS, Nagam V, Bobbu P, Ghosh SB, Tartte V (2015) First report of biomimetic synthesis of silver nanoparticles using aqueous callus extract of Centella asiatica and their antimicrobial activity. Appl Nanosci 5(7): 801-807. https://doi.org/10.1007/s13204-014-0374-6

25. Oke R, Thombre R, Pande AK (2015) Synthesis of plant-mediated silver nanoparticles using Tylophora indica Merr. (Pittakari) leaf extract and evaluation of its antimicrobial and anticancer activity. Int J Phar Bio Sci 6:311-318

26. Kumari J, Singh A (2016) Green synthesis of nanostructured silver particles and their catalytic application in dye degradation. J Gen Eng Bio 14(2):311317. https://doi.org/10.1016/j.jgeb.2016.09.005

27. Prakash MB, Paul S (2012) Green synthesis of silver nanoparticles using Vincaroseus leaf extract and evaluation of their antimicrobial activities. Int J Appl Bio Pharm Tech 3(4):0976-4550. https://doi.org/10.1016/j.closurfb.2013. 03.017

28. Rajeshkumar S, Kannan C, Annadurai G (2012) Synthesis and characterization of antimicrobial silver nanoparticles using marine brown seaweed Padina tetrastromatica. Drug Today 4(10):511-513
29. Duncan DB (1955) Multiple range and multiple $F$ test. Biometrics 11:1-42

30. Padman AJ, Henderson J, Hodgson S, Rahman PK (2014) Biomediated synthesis of silver nanoparticles using Exiguobacterium mexicanum. Bio Lett 36(10):2079-2084. https://doi.org/10.1007/s10529-014-1579-1

31. Ali A, Mohammad S, Khan MA, Raja NI, Arif M, Kamil A, Mashwani Z (2019) Silver nanoparticles elicited in vitro callus cultures for accumulation of biomass and secondary metabolites in Caralluma tuberculate. Artif Cells Nanomed Biotechnol 47(1):715-724. https://doi.org/10.1080/21691401.201 9.1577884

32. Blanco E, Shen H, Ferrari M (2015) Principles of nanoparticle design for overcoming biological barriers to drug delivery. Nat Biotechnol 33(9):941951. https://doi.org/10.1038/nbt.3330

33. Lombardo D, Kiselev MA, Caccamo MT (2019) Smart nanoparticles for drug delivery application:Development of versatile nanocarrier platforms in biotechnology and nanomedicine. J Nanomater:1-26. https://doi.org/10.11 55/2019/3702518

34. Thomas TD, Philip B (2005) Thidiazuron-induced high-frequency shoot organogenesis from leaf-derived callus of a medicinal climber, Tylophora Indica (Burm. F.) Merrill. In Vitro Cell Dev Bio-Plant 41(2):124-128. https://doi. org/10.2307/4293828

35. Rao MS, Purohit SDN (2006) In vitro shoot bud differentiation and plantlet regeneration in Celastrus paniculatus Willd. Bio Plantarum 50(4):501-506. https://doi.org/10.1007/s10535-006-0079-0

36. Gowdru HB, Rajashekarappa S, Malleshappa KH, Maruthi KR, Krishna V (2011) In Vitro Regeneration of Inflorescence and Callus Enhancement of Celastrus paniculatus Willd. Med Aromatic Plant Sci Biotechnol 5(2):147-151

37. Swamy MK, Sudipta KM, Jayanta K, Balasubramanya S (2015) The green synthesis, characterization, and evaluation of the biological activities of silver nanoparticles synthesized from Leptadenia reticulata leaf extract. Appl Nanosci 5(1):73-81. https://doi.org/10.1007/s13204-014-0293-6

38. Noginov M, Zhu G, Bahoura M, Adegoke J, Small C, Ritzo BA, Drachav VP, Shalaev VM (2007) The effect of gain and absorption on surface plasmonsin metal nanoparticles. Appl Phy B 86(3):455-460. https://doi.org/10.1007/ s00340-006-2401-0

39. Suvith VS, Philip D (2014) Catalytic degradation of methylene blue using biosynthesized gold and silver nanoparticles. Spectrochimic Acta Part A 118 : 526-532. https://doi.org/10.1016/j.saa.2013.09.016

40. Gopinath V, MubarakAli D, Priyadarshini S, Priyadharsshini NM, Thajuddin N, Velusamy P (2012) Biosynthesis of silver nanoparticles from Tribulus terrestris and its antimicrobial activity: a novel biological approach. Coll Surf B96:6974. https://doi.org/10.1016/j.colsurfb.2012.03.023

41. Basavegowda N, Idhayadhulla A, Lee YR (2014) Preparation of Au and Ag nanoparticles using Artemisia annua and their in vitro antibacterial and tyrosinase inhibitory activities. Mater Sci Eng C43:58-64. https://doi.org/10.1 016/j.msec.2014.06.043

42. Bindhu MR, Umadevi M (2013) Synthesis of monodispersed silver nanoparticles using Hibiscus cannabinus leaf extract and its antimicrobial activity. Spectrochim Acta Part A 101:184-190. https://doi.org/10.1016/j.saa.2 012.09 .031

\section{Publisher's Note}

Springer Nature remains neutral with regard to jurisdictional claims in published maps and institutional affiliations.

\section{Submit your manuscript to a SpringerOpen ${ }^{\circ}$ journal and benefit from:}

- Convenient online submission

- Rigorous peer review

- Open access: articles freely available online

- High visibility within the field

- Retaining the copyright to your article

Submit your next manuscript at $>$ springeropen.com 